Supplement of Nat. Hazards Earth Syst. Sci., 20, 2503-2519, 2020

https://doi.org/10.5194/nhess-20-2503-2020-supplement

C Author(s) 2020. This work is distributed under

the Creative Commons Attribution 4.0 License.

(c) (1)

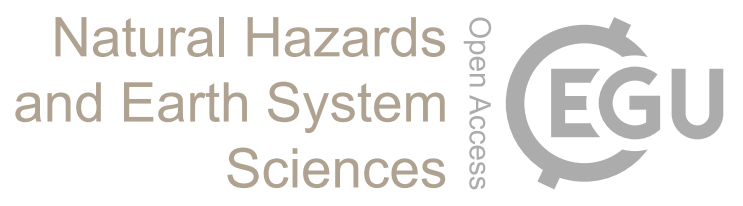

Supplement of

\title{
The object-specific flood damage database HOWAS 21
}

Patric Kellermann et al.

Correspondence to: Heidi Kreibich (heidi.kreibich@gfz-potsdam.de)

The copyright of individual parts of the supplement might differ from the CC BY 4.0 License. 


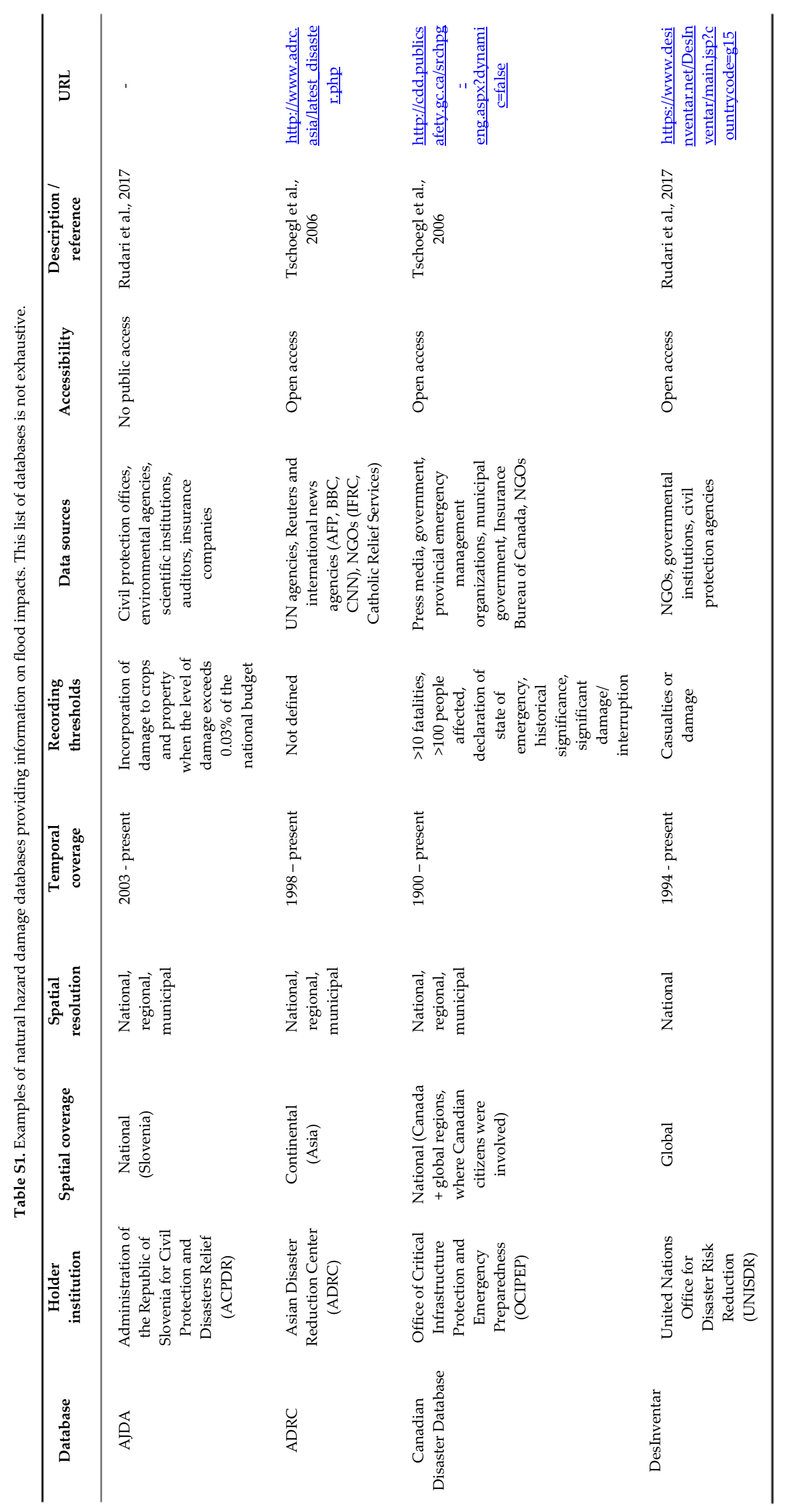




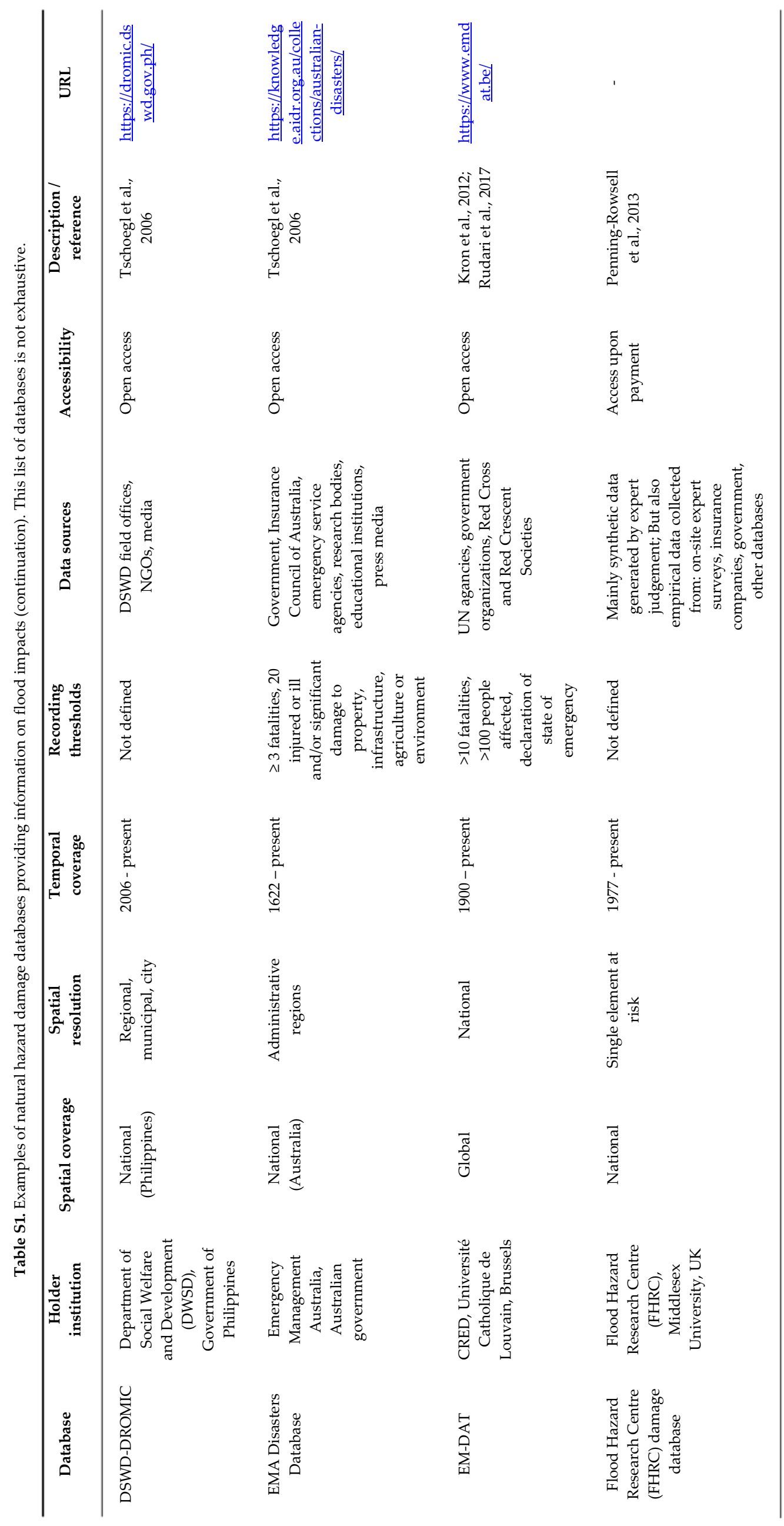




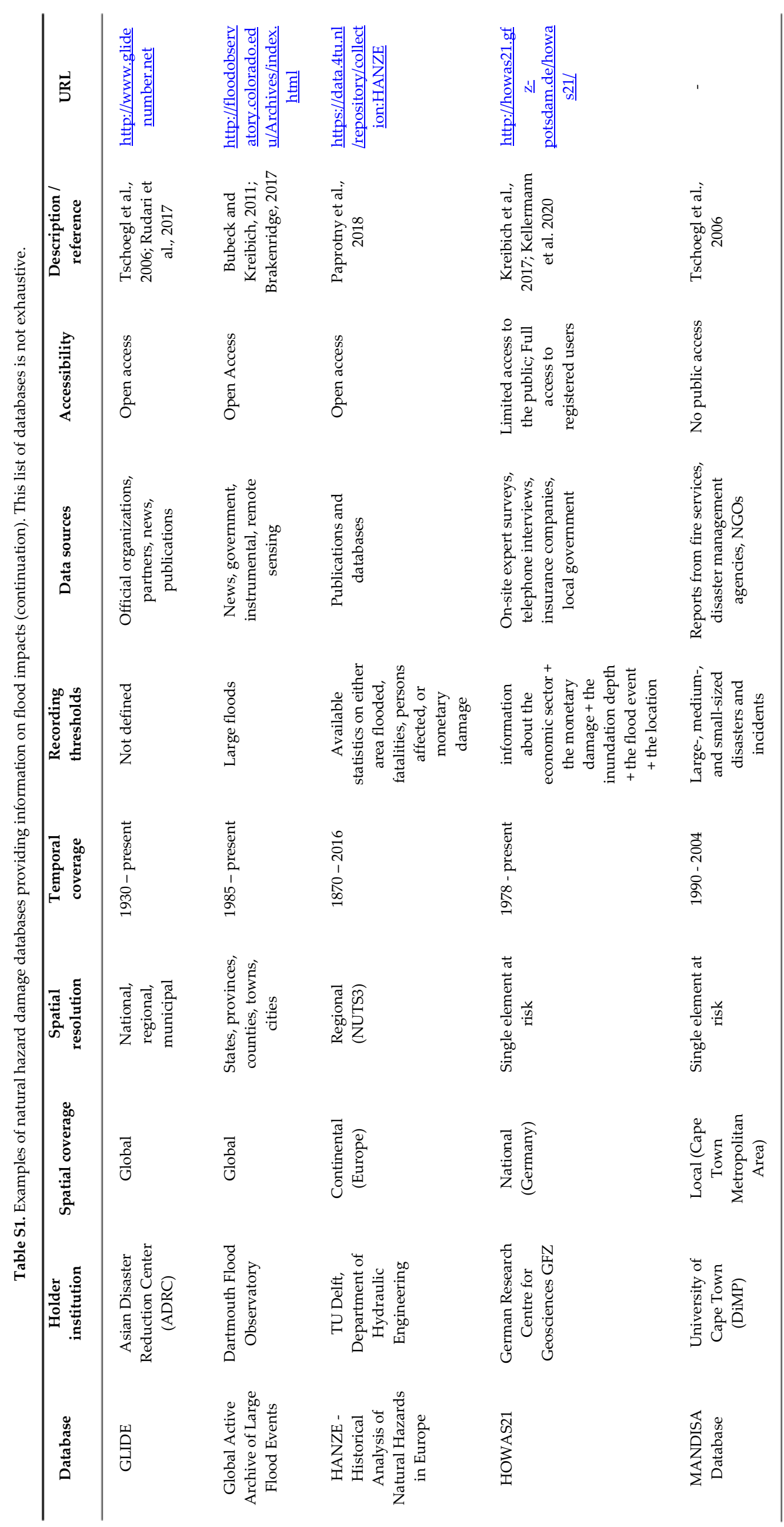




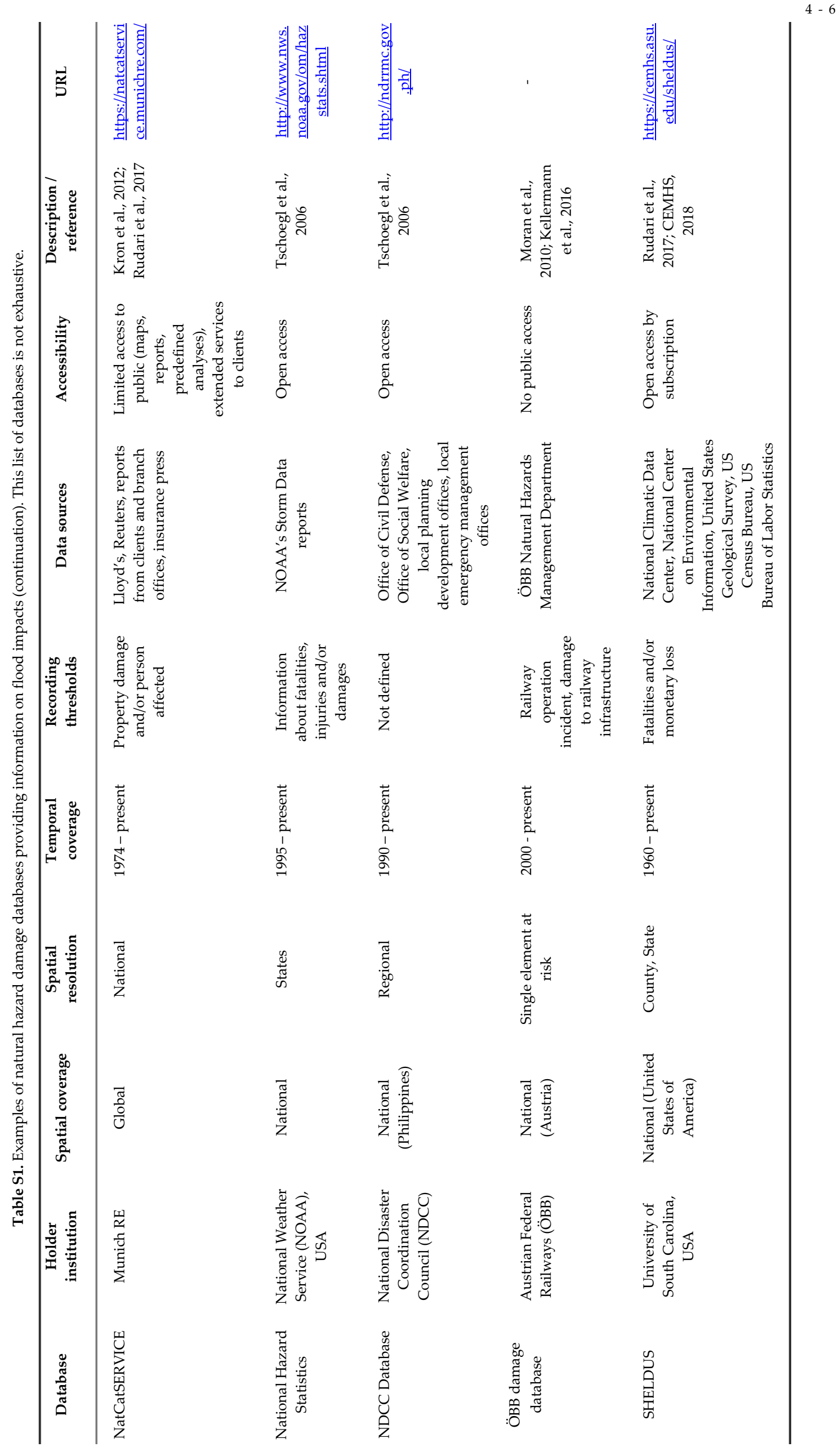




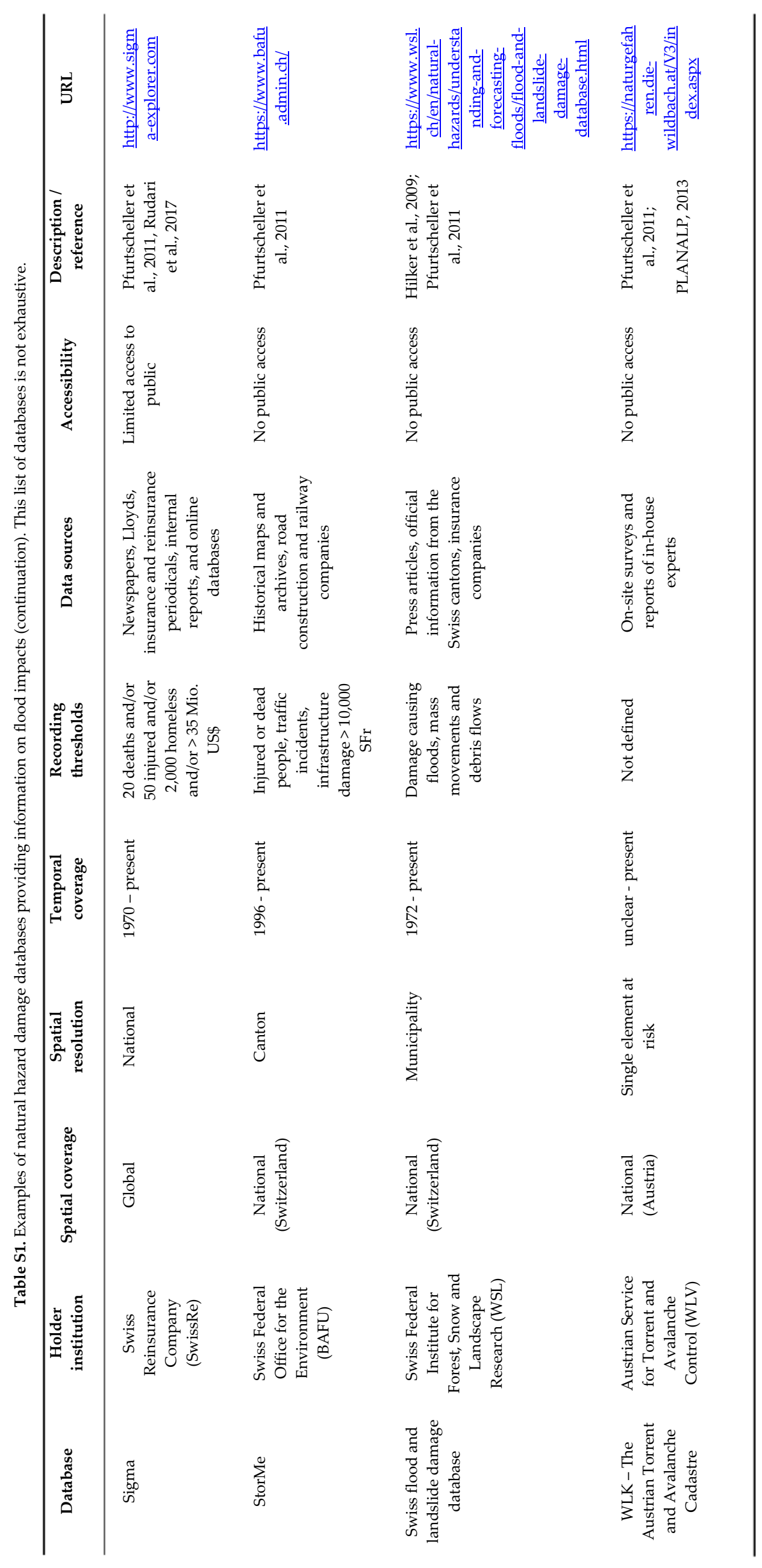




\section{References}

Brakenridge, G. R.: Global Active Archive of Large Flood Events, Dartmouth Flood Observatory, University of Colorado, available at: http://floodobservatory.colorado.edu/Archives/index.html (last access: 10.09.2020), 2017.

Bubeck, P. and Kreibich, H.: Natural Hazards: Direct costs and losses due to the disruption of production processes, CONHAZ WP1 Final Report, GFZ, Potsdam, Germany, available at: https://www.ufz.de/export/data/2/122161_CONHAZ\%20REPORT\%20WP01_2.pdf (last access: 10.09.2020), 2011.

CEMHS: Spatial Hazard Events and Losses Database for the United States, Version 16.1. Phoenix, AZ, Center for Emergency Management and Homeland Security, Arizona State University, 2018.

Hilker, N., Badoux, A., and Hegg, C.: The Swiss flood and landslide damage database 1972-2007, Nat. Hazards Earth Syst. Sci., 9, 913-925, https://doi.org/10.5194/nhess-9-913-2009, 2009.

Kellermann, P., Bubeck, P., Otto, A., Kundela, G., Schönberger, C., Kirnbauer, R., Schöbel, A., Aksentijevic, J., and Thieken, A. H.: Building railway transport resilience to alpine hazards, in: ENHANCE: Novel Multi-Sector Partnerships in Disaster Risk Management, Results of the ENHANCE project, edited by: Aerts, J. and Mysiak, J., EU FP7 project ENHANCE, Brussels, pp. 346, 2016.

Kellermann, P., Schröter, K., Thieken, A.H., Haubrock, S.N. and Kreibich, H.: The object-specific flood damage database HOWAS 21, Nat. Hazards Earth Syst. Sci., 2020.

Kreibich, H., Thieken, A. H., Haubrock, S. and Schröter, K.: HOWAS 21, the German Flood Damage Database, in: Flood Damage Survey and Assessment, edited by: Molinari, D., Menoni, S., and Ballio, F., Geoph. Monog. Series, chap. 5, 6575, https://doi.org/10.1002/9781119217930.ch5, 2017.

Kron, W., Steuer, M., Löw, P., and Wirtz, A.: How to deal properly with a natural catastrophe database - analysis of flood losses, Nat. Hazards Earth Syst. Sci., 12, 535-550, https://doi.org/10.5194/nhess-12-535-2012, 2012.

Moran, A., Thieken, A., Schöbel, A., and Rachoy, C.: Documentation of flood damage on railway infrastructure, in: Data and mobility. Transforming information into intelligent traffic and transportation, edited by: Düh, J., Hufnagl, H., Juritsch, E., Pfliegl, R., Schimany, H., and Schönegger, H., Springer, 2010.

Paprotny, D., Morales-Nápoles, O., and Jonkman, S. N.: HANZE: a pan-European database of exposure to natural hazards and damaging historical floods since 1870, Earth Syst. Sci. Data, 10, 565-581, https://doi.org/10.5194/essd-10-565-2018, 2018.

Penning-Rowsell, E., Priest, S., Parker, D., Morris, J., Tunstall, S., Viavattene, C., Chatterton, J., and Owen, D.: Flood and Coastal Erosion Risk Management, London, Routledge, 2013.

Pfurtscheller, C., Lochner, B., and Thieken, A. H.: Costs of Alpine Hazards, CONHAZ WP8 Final Report, Innsbruck, Austria, available at: https://www.ufz.de/export/data/2/122168_CONHAZ\%20REPORT\%20WP08_1.pdf (last access: 10.09.2020), 2011.

PLANALP: Alpine strategy for adaptation to climate change in the field of natural hazards, Platform on Natural Hazards of the Alpine Convention, Federal Office for the Environment FOEN, Bern, Switzerland, 2013.

Rudari, R., Massabò, M., and Bedrina, T.: Overview of Loss Data Storage at Global Scale, in: Flood Damage Survey and Assessment, edited by: Molinari, D., Menoni, S., and Ballio, F., Geoph. Monog. Series, chap. 3, 31-51, https://doi.org/10.1002/9781119217930.ch3, 2017.

Tschoegl, L., Below, R., and Guha-Sapir, D.: An Analytical Review of Selected Data Sets on Natural Disasters and Impacts, UNDP/CRED Workshop on Improving Compilation of Reliable Data on Disaster Occurrence and Impact, 2-4 April 2006, Bangkok, Thailand, available at: http://www.cred.be/sites/default/files/TschoeglDataSetsReview.pdf (last access: 10.09.2020), 2006. 